\title{
Comments on the Probate Code of California
}

\author{
Statutory Changes Made by the Probate Code*
}

Having drafted the Probate Code, which took effect on August 14th, 1931, I am now indulging in the pleasure of criticising it. Not that I consider it a bad job; but while working upon the revision numerous changes occurred to me as being advisable, or at least well worthy of

* The Code Commission gave careful consideration to the question whether or not an act providing for a Probate Code would be constitutional, particularly in view of the decision in Lewis v. Dunne (1901) 134 Cal. 291, 66 Pac. 478. The first point mentioned in Lewis v. Dunne as a ground for holding the act which attempted to revise the Code of Civil Procedure to be unconstitutional, was that the amended law was not re-enacted in its entirety, as required by section 24 of Article IV of the California Constitution. It is difficult to see bow this point can be made against the Probate Code, which does re-enact the revised law, that is, the law relating to probate, in its entirety. The act does not purport to be a revision of the Code of Civil Procedure. If the act had been so entitled, of course, the enactment of only those laws relating to probate would be subject to the first objection raised in Lewis v. Dunne.

The second ground mentioned in Lewis v. Dunne for holding the act there under consideration to be unconstitutional was that the act did not relate to a single subject as required by section 24 of Article IV of the state constitution. It was pointed out that the Code of Civil Procedure does not constitute a single subject because it deals not only with civil procedure, but with many other things such as mechanics' liens, etc., and that it was merely "a collection of laws" not upon any one subject but upon several subjects. Judge Beatty disagreed with this conclusion, but we can concede the full force and effect of the point made without it having any bearing upon the Probate Code.

The most serious question with regard to the constitutionality of the Probate Code which the Commission had to consider was whether or not guardianship proceedings were sufficiently related to wills, succession and administration of estates as to be included within a single subject. Ever since the enactenent of the Code of Civil Procedure, which was prior to the adoption of the present constitution, Title XI, Part III, dealt with "proceedings in probate courts." The proceedings referred to included both estates of decedents and minor and incompetent wards. In both cases the court is authorized to deal with the property and persons of those unable to attend to their own affairs, either because they have died or have not reached the age of majority, or have not sufficient mental capacity. The procedure for dealing with estates of decedents and minors has always been to a great extent the same, or similar.

The Supreme Court of Minnesota has held that an act creating a probate code dealt with but a single subject, Jolinson v. Harrison (1891) 47 Minn. 575, 50N.W.923, $28 \mathrm{Am}$. St. Rep. 382. The following California cases have some bearing upon the question, and would tend to sustain the contention that the act adopting a probate code is constitutional:

Ex Parte Liddell (1892) 93 Cal. 633, 29 Pac. 251;

Ex Parte Miller (1895) 109 Cal. 643, 42 Pac. 428;

Robinson v. Kerrigan (1907) 151 Cal. 40, 90 Pac. 129 ;

Buelke v. Levenstadt (1923) 190 Cal. 684, 214 Pac. 42.

The nine members of the Code Commission came to the conclusion that there was no reasonable doubt as to the constitutionahity of the act, and they were so advised informally by Deputy Attorney-General Robert W. Harrison. 
consideration and discussion, which the code commission felt were of a character sufficiently controversial to preclude their adoption by the commission, whose task was primarily the restatement of the law. Only such changes in the substance of the law have been incorporated in the Probate Code as were considered to be so plainly meritorious as to be practically non-controversial.

In the March, 1931, number of the State Bar Journal, there is an article explaining the general framework of the new Probate Code. As is shown by that article more in detail, the provisions of law dealing with probate have been rearranged in logical sequence and the language has been revised to a considerable extent, so that much useless verbiage has been eliminated; ambiguous expressions have been clarified; long sections subdivided, and short sections consolidated. About thirty court decisions have been codified and numerous minor changes were effected for the purpose of simplicity and uniformity.

An article in the July, 1931, number of the State Bar Journal contains a synopsis of the actual changes in the law, which are about eighty in number. This present paper is not intended to cover that ground, although some of the changes are of sufficient importance and interest to be noted here. The following are the more important changes in the law which are brought about by the adoption of the new code, the numbers referring to the sections of the Probate Code:

Sec. 70. The old law provided for the complete revocation of a will upon the marriage of the testator or testatrix, unless the spouse were sufficiently mentioned or provided for. For example, a man may have made a will in favor of his sister to the exclusion of his father (his heir); should he then have married without having made provision for his wife, not only would the wife have taken her share of his estate as an heir, but the father would have taken the remainder of the property, which portion, at least, had been intended for the sister. It was so held in the Estate of Ryan. ${ }^{1}$ By the provisions of the new act, such a will will be revoked only as to the spouse.

Sec. 382. The procedure for contesting a will after probate is made to conform to the present practise with respect to a contest before probate. That is, a citation shall be served and issue joined before the case is set for trial, instead of having the citation specify a definite return day, when the parties had to be ready for trial, even though there were a demurrer to the contest which had not yet been ruled upon.

Sec. 421. The old law absolutely prohibited the appointment of a surviving partner as administrator. If two brothers were partners, and one had died intestate, leaving the surviving brother as his only heir, the

1 (1923) 191 Cal. 307, 216 Pac. 366; Note (1923) 12 CALIF. L. REv. 56. 
public administrator would lave stepped in to administer the estate. I am informed that such a case arose not long ago in Monterey County. The new law merely provides that the surviving partner must not be appointed "if any person interested in the estate objects to his appointment."

Sec. 575. The new law will permit the administrator to institute an action for partition when the decedent was the owner of an undivided interest in any property, provided he obtains an order from the court authorizing him to do so, after due notice and a liearing. Formerly he could not institute such an action.

Sec. 630. This section relates to property of a decedent which may be transferred without administration ${ }^{2}$ upon presentation of an affidavit. The affiant must now show, in addition to his relationship to the decedent, that he is entitled to succeed to the property. As amended in the assembly this section includes "money due to the decedent as wages," the affidavit of the claimant, slowing that he is within the purview of the section, being a sufficient acquittance to the eniployer.

Sec. 681. Formerly an order for family allowance ceased with the filing of an inventory, whereupon it was necessary to obtain a new order. Now an order for family allowance made before the filing of the inventory will continue in force until there is a petition for its modification.

Sec. 730. A judgment in favor of the claimant, in a suit upon a rejected claim, formerly did no more than rank the claim as an allowed claim, making it still subject to attack upon the filing of the administrator's account, whereupon the controversy would be renewed. Now a judgment in favor of the claimant, when it becomes final, conclusively establishes the validity of the claim.

Sec. 844. An administrator may now lease real property without an order of court where the tenancy is from month to month or for a term not extending beyond the time for presenting claims and the rental does not exceed $\$ 100$ a month.

Sec. 860. In 1929 a new section was added to the Code of Civil Procedure authorizing an administrator to exchange property of the estate for other property. Under that section lie would proceed to make the exchange without order of court, and then seek its confirmation in the mauner provided for confirmation of sales. Under the new procedure he must seek the authority of the court to make the exchange, and notice must be given of the hearing of his petition.

Sec. 950 . Wages to the extent of $\$ 100$ for each employee of the decedent, for services rendered within sixty days prior to death, have constituted a preferred claim. As amended in the assembly, this preference is

2 Money in bank, property in safe deposit boxes, sbares of corporate stock, etc., come under this provision. 
enlarged to cover the sum of $\$ 200$, for services rendered within ninety days prior to the death.

Secs. 1080-2. Section 1664 of the Code of Civil Procedure ${ }^{3}$ was enacted to fit the circumstances of the claim of heirship made in the Blythe Estate, which was in probate for many years without being ready for distribution. It provided a long and cumbersome proceeding, with several ambiguous provisions. The substituted sections provide simply that when the time to present claims has expired but the estate is not in a condition to be closed any one may file a petition setting forth his claim and praying that the court determine who are entitled to distribution of the estate. Notice of the hearing is given as in the case of a petition for distribution. It would seem that if a ten days notice by posting is sufficient to authorize the court to distribute an estate, it should be sufficient for the purpose of determining interests in the estate, when the estate is not in a condition to be closed.

Secs. 1100-6. These sections make provision for the partition, allotment or division of property before distribution, when two or more heirs, devisees or legatees are entitled to the distribution of undivided interests in any property of the decedent, and they have not agreed among themselves to such division. The allotment shall be controlling upon the proceedings for distribution, "unless modified for good cause upon reasonable notice," and the proceedings leading to such allotment may be reviewed upon appeal from the decree of distribution.

Sec. 1120. The power of the probate court with respect to the administration of a trust after distribution is enlarged so as to authorize proceedings for instructions to the trustee.

Sec. 1126. The jurisdiction of the probate court is extended to proceedings for the appointment of a new trustee when a vacancy in the trusteeship occurs after distribution. In the past a suit in equity was necessary, and very often difficulties arose with respect to service of summons upon beneficiaries of the trust, especially where they or some of them were non-residents.

\section{Court Decistons Which Have Been Codified}

About thirty decisions of the Supreme Court and of the District Courts of Appeal of California have been codified in the new Probate Code. The cases selected for codification are those which are based upon serious ambiguities or omissions in the statutory law. The most important instances are the following:

Sec. 50. When the testator sigus or publishes his will, must both attesting witnesses be present, or may he acknowledge or declare it to one and then to the other? The statute provided that "the subscription

${ }^{3}$ Sometimes known as the Blythe Act. 
must be made in the presence of the attesting witnesses, or be acknowledged by the testator to them to have been made by him or by his authority," that at the same time he must "declare to the attesting witnesses that the instrument is his will," and that "there must be two attesting witnesses." There was no express provision that the witnesses had to be present together, but such an intendment was read into the statute by the decision in Estate of Emart, ${ }^{4}$ although neither Judge Bardin in the trial court, nor Judge Sloss nor Judge Angellotti, who dissented from the judgment of reversal, could find this requirement in the statute. The new section removes the ambiguity by providing that the subscription or acknowledgment must be in the presence of "both of the attesting witnesses, present at the same time."

Secs. 228-9. If the testator left a surviving wife, could he be considered to have been at the time of his death "a widower?" Subdivision 8 of section 1386 of the Civil Code provided that "If the deceased is a widow or widower and leaves no issue" and the estate or any portion thereof was the separate property of the decedent's deceased spouse, or was community property of the decedent and his or her deceased spouse, the relatives of the predeceased spouse, under certain circumstances, would inherit the estate or a portion thereof. It was held in Estate of $M c A r t h u r$, , that the words "widow or widower" appearing in the statute did not necessarily refer to the status of the testator at the time of his death, but might refer to a previous status, so that Mrs. McArthur, having been married twice, was held to be a widow, notwithstanding the fact that she was a married woman at the time of her death and left a husband surviving.

Some of the strange consequences of this decision are pointed out in an article in the March, 1931, issue of this Review. ${ }^{6}$ To safeguard against the possibility that any one may in the future believe that a widow or widower is necessarily a person having no living spouse, the words "widow or widower" are left out of the new statute, so as to conform to the decision of the supreme court. Whether the decision is correct, or whether the law as construed by the court is desirable, are matters interestingly covered by the note just referred to, and to which I shall advert briefly in the latter part of this article.

Sec. 257. The fact that an adopted child succeeds to the estate of one who has adopted him, the same as a natural child, and does not succeed to the estate of the natural parent, and the fact that the person adopting succeeds to the estate of the adopted child the same as a natural parent, and that the natural parent is no longer entitled to succeed, have

4 (1917) 175 Cal. 238, 165 Pac. 707; Note (1919) 8 CaITr. L. REv. 124.

5 (1930) 210 Cal. 439, 292 Pac. 467.

6 Note (1931) 19 CaIIF. L. Rev. 313. 
not hitherto been ascertainable from the statutory law, but these were the holdings in In re Nerman, ${ }^{7}$ and Estate of Jobson. ${ }^{8}$ The law as determined by these decisions is now expressed in the statute.

Sec. 385. When a will has been admitted to probate and the time to contest the same has passed, may another document be offered for probate and established as the true will? It was so held in Estate of Moore, ${ }^{9}$ and is so stated in this new section.

Sec. 631. When the statute gives certain relatives of a decedent the right to withdraw money from bank, property from safe deposit boxes, etc., upon the furnishing of an affidavit of relationship, does this give the designated relative title to the money so withdrawn or to the property so delivered? It was held in Brezzo v. Brangero, ${ }^{10}$ that title does not pass and that the property is still subject to administration if necessary, and the substance of this decision is now contained in this section of the new code.

Sec. 713. What standing is given to a claim by its allowance by the administrator. and approval by the judge? It was held in Estate of Swain, ${ }^{11}$ that such allowance and approval did not prevent the claim being contested when the administrator filed his account and report, and the statute now expressly so states.

\section{Further Changes Suggested for Consideration}

The legal profession in California is, I believe, quite satisfied that the general scheme of the present probate practice should be retained. The essence of this scheme is a determination by court procedure of the persons having claims against the estate, and of the persons to whom title has passed by virtue either of the will of the decedent or of the statute of succession. It is possible, however, to abbreviate and simplify the proceedings to some extent, and the question arises what changes can be made in this direction without jeopardizing any interests which the present procedure now protects. Also, there are certain provisions in the present law the policy of which may be questioned. I would like to submit for consideration and discussion by the profession a number of such changes which have occurred to me or have been suggested to me. They will be taken up in the order in which the related subjects are set forth in the Probate Code.

\section{Wills}

Sec. 25 now provides that "The execution of a codicil referring to a previous will has the effect to republish the will as modified by the

7 (1888) 75 Cal. 213, 16 Pac. 887.

8 (1912) 164 Cal. 312, 128 Pac. 938; Note (1913) 1 CarIF. L. Rev. 259.

9 (1919) 180 Cal. 570, 182 Pac. 285.

10 (1921) 51 Cal. App. 79, 196 Pac. 87.

11 (1885) 67 Cal. 637, 8 Pac. 497. 
codicil." The provision is of questionable value. This rule was originally adopted so as to extend the effect of a will to cover property acquired after the date of the will. Since all wills now speak as of the date of death, there is no need for the declaration, and on the other hand it may be the cause of considerable trouble.

The question has arisen as to the effect of the death of the testator within thirty days after the execution of a codicil, by reason of the strictures upon charitable bequests which are valid only if the will is made thirty days before death. It was leeld in Estate of McCauley, ${ }^{12}$ that the death of the testator within thirty days after the execution of a codicil did not prevent the charitable bequests in the will taking effect where the original will was executed thirty days before the death, as it was not considered that the will was "republished" to this extent. However, a situation arose in Estate of Matthews, ${ }^{13}$ which shows the difficulty of giving the proper interpretation to the provision of law which is under discussion. By the testator's will he left $\$ 10$ to his daugter. After the daughter's death he executed a codicil which made no mention of the daughter or of ler death, or of her son, who survived her. It was held that the will was republished as of the date of the codicil, and that the grandson was a pretermitted heir. If the codicil had not been executed, the son would have taken only $\$ 10$. Why should a codicil which, let us say, merely gave $\$ 1,000$ to the University of California for a scliolarship, have the effect of nicreasing the grandson's share in the estate from $\$ 10$ to a more substantial amount? The codicil, instead of renewing the declaration of the will, upsets the will.

If there is any virtue in retaining the present section, it at least should be modified by sone such clause as the following:

"but the mere republication shall not operate to destroy or alter the effect of any provision of the will which is not intentionally dealt with by the codicil, either directly or indirectly, and which would take effect but for the change of the effective date of the will, caused by its republication." However, such a clause is cumbrous, and unless the present section serves some useful purpose, which I do not perceive, I would suggest its repeal.

Sec. 26. The will of a non-resident nuay be given effect in the disposition of personal property located in California even though the will does not conform to the requirenents of the California law as to the execution of wills, provided the will is valid according to the law of the testator's domicile. Prior to the adoption of the Probate Code, the will must also lave been executed in the state of domicile. Formerly, if a resident of Salt Lake City, on his way by train to San Francisco, were to have executed a will while passing through the State of Nevada, it would not

13 (1917) 176 Cal. 576, 169 Pac. 322 ; Note (1918) 6 CatrF. L. Rev. 312. 
have been given effect here, even though it comphed with the formalities prescribed by the laws of Utah. Now, such a will can be probated.

The further question arises, however, why should not the will of a nonresident be given effect, at least as to personalty, if valid according to the law of the state where it is executed? Let us assume that the laws of Utah and Nevada differ as to the formalities required in executing a will. A man executes a will in Reno conforming to the law of the State of Nevada. If he is a resident of Nevada it may be given effect in California, but if he is a resident of Utah it will not be given effect unless it conforms to the laws of Utah. Is there any value in this limitation?

Sec. 27. Only the sorts of corporations mentioned in the statute may take by will. The hist has been increased from time to time, and by amendment at the last session includes religious corporations and unincorporated religious associations. Why bother about the restrictions that yet remain? No very good reason occurs to me why a person should not leave his property to a corporation if he desires to do so. Perhaps the same restrictions might be impesed that are now imposed upon charitable bequests.

Sec. 43. If a decedent leaves neither spouse, issue nor parent, he may leave as much of his estate as he chooses to charity, provided the will is executed at least six months prior to his death. Why six months? Even where he leaves a spouse, or issue, or a parent, he may make a charitable bequest of at least one-third of his estate, provided the will is executed thirty days before death. If thirty days is sufficient time to think the matter over in the one case, why not in the other?

Sec. 50. As has already been pointed out, the law had been interpreted to require both witnesses to a will to be present at the same time when a testator acknowledged his signature and declared the instrument to be his will, and the statute now clearly expresses this requirement. But is there any need for this provision? A holographic will may be given effect even though there be no witnesses to its execution. It may be extremely inconvenient to have both of the desired witnesses present at the same time. Why not permit the testator to acknowledge his signature and declare his will to the second witness after the first witness has left?

Sec. 53. The effect of a holographic will is destroyed if any word is incorporated which is not in the handwriting of the testator. Why should not the statute be liberalized so as to ignore any word or phrase not in the handwriting of the decedent which makes no difference in the meaming of the will, that is, if the will must be given the same interpretation and effect whether the printed or stamped words are in the will or not? See Estate of Thorn, ${ }^{14}$ where the mere whimsical use of a rubber stamp with

14 (1920) 183 Cal. 512, 192 Pac. 19; Note (1929) 17 CALIF. L. REv. 297. 
the word "Cragthorn" was held to invalidate the will, although the property designated by this name was otherwise completely identified by words in the testator's own handwriting. Such liberalization of the statute would prevent any future will being denied probate upon such an aimless technicality as upset the Thorn will.

Sec. 54. A nuncupative will may be made by anyone anticipating immediate death from an "injury," if the testator should die the same day that he receives the injury. If oral wills are to be recognized at all, why should not a person be permitted to make such a will if he anticipates death from any perilous situation, whether he has yet received an injury or not? The law will give effect to the verbal will of an uninjured person if he is in military service in the field or doing duty on shipboard at sea, and is anticipating or fearing death. Why should these be the only perilous situations in which a man may express his testamentary desires orally?

The fact of military service, or of employment on shipboard, or of a physical injury, it is true, is not one which could be so easily fabricated as the broader fact of "perilous situation." But if death results upon the day in question, the likelihood of there having been a perilous situation is sufficiently probable to make this distinction of little consequence.

Sec. 71.5. It was proposed at the last session of the legislature to add a new section to the Probate Code, to be numbered 71.5, to provide that when the testator's marriage has been dissolved by a decree of divorce, or when an interlocutory judgment has been rendered declaring that either party to the marriage is entitled to a divorce, and such decree continues in force, or if the marriage is annulled, the will should be revoked as to the person who was the spouse or purported spouse of the testator. This proposal was not adopted, but I think it merits further consideration. This change of status by the dissolution of the marriage is as important as the change of status by a marriage entered into after the making of a will. A number of other states take this view and provide that a will is revoked by divorce.

Sec. 72. In re Hickman, ${ }^{15}$ declared that a will should be admitted to probate even though the sole beneficiary had died and the only effect that could be given to the document was the appointment of an executor. But Estate of Iburg, ${ }^{16}$ held that where a second will made a disposition of property completely at variance with that made by a prior will, the first will was revoked, even though it provided for the appointment of an executor and the second will made no reference to such an appointment. It was held, in effect, that the appointment of an executor was not a part of a will, but a mere incident. The court attempted to reconcile 
its decision with the Hickman case, but it is questionable whether it succeeded.

It seemed to the code commission that the naming of an executor in a document not expressly revoked should at least in some cases be given effect, where the second will makes no attempt to alter this provision; so the following clause was inserted in the statute relating to the revocation of a will by the execution of a later will containing provisions inconsistent with the former:

"but the mere naming of an executor in the prior will need not be given effect by the court when the subsequent will is otherwise wholly inconsistent with the terms of the prior will, the intention of the testator in this respect being left to the determination of the court."

For example, if the executor named in the first will was the sole or a substantial beneficiary thereunder, and the second will left the entire estate to other perons, it is reasonable to suppose that the testator did not intend the mere naming of the executor to be given effect. If, on the other hand, the executor named is a brother or partner of the testator, or a trust company, to whom nothing is left by the will, and the second will, makes a complete change in the disposition of the property but makes no reference to an executor, it is quite probable that the testator intended the appointment of the uninterested executor to stand. Perhaps it would be better to provide, specifically, that the appointment shall be given effect except where the person nominated is a beneficiary under the first will and is not under the second.

Sec. 74 , relating to revocation, ${ }^{17}$ contains the declaration that if a will is destroyed by someone other than the testator the will is not revoked unless the direction of the testator and the fact of destruction is proved by two witnesses. In the absence of the testimony of such two witnesses the will, then, is not revoked. But how is it to be given effect? Section $350,{ }^{18}$ declares that no will destroyed in the testator's lifetime shall be proven unless it is shown to have been destroyed fraudulently or by public calamity, without the testator's knowledge.

In other words, one section declares that where the will is destroyed, let us say by accident, it is not revoked, but the other section says that it cannot be established as a will. For all practical purposes, the declaration of section 74 that the will is not revoked is ineffective.

Sec. 75. A man executes two successive wills, keeping them both in his possession. The second will expressly revokes the first. Later on he tears up the second will, but retains the first among his effects. The statute declares that the revocation of the second will does not revive the first will. But this declaration would seem to fly right in the face of

17 Taken from CAL. CIv. CODE $\$ \$ 1292,1293$.

18 Taken from Cax. Code CIv. Proc. \$1339. 
the ordinary intendment of the testator, as judged by his acts. Would it not be better to restore the earlier rule to the effect that the destruction of the will containing the revoking clause does revive the first will?

The present law leaves an opening for the commission of fraud. Whenever a will is filed, although it may be the only one physically in existence, evidence may be offered that someone saw a later will which contained a clause revoking all prior wills, and that the alleged second will has disappeared, presumably having been destroyed by the testator. The testimony of but one witness as to the contents of the missing will is sufficient, since it has been held that this is not an attempt to "prove" the lost will. ${ }^{19}$

As it is the policy of the law to require wills to be in writing, it would seem to be madvisable to permit the effect of the only existing document to be nulbified by oral testimony as to another alleged will which is no longer extant.

Another curious result of the present section would be brought about under the following circumstances: A person executes a will leaving all of his property to $A$. He then executes a second will, in the nature of a codicil, leaving $\$ 10,000$ to $B$. This revokes the first will pro tanto. Changing his mind with regard to the legacy to $B$, the testator destroys the codicil. When $A$ offers the first will, it can be shown that the testator died intestate to the extent of $\$ 10,000$ by reason of the execution and subsequent revocation of the codicil.

Sec. 90. A child not mentioned by the testator will take by succession, upon the theory that the parent has overlooked his existence or has slipped up in enumerating his progeny. There are few families so large, at the present day, that a parent is apt to overlook any of his living offspring for whom he intends to provide by his will. There are undoubtedly many more cases where the testator does not know the effect of the law and believes that no one will get his property who is not mentioned in the will. A friend once showed me a will which he had written himself, upon the receipt of an inheritance, and asked me if it were a valid will. It was holographic, properly dated and signed, and read substantially as follows:

"I hereby leave all of my property to my wife, Mary, and appoint

her executrix of this will to serve without bonds."

I told him it was a perfectly good will. "Of course," I added, "you realize that your wife will get only one-third of your separate estate, because two-thirds will go to your infant sons, who are not mentioned in the will?" Of course, on the contrary, he wanted to avoid leaving any part of his property to his children, who were only five or six years old.

19 Estate of Johnson (1922) 188 Cal. 336, 206 Pac. 628; Estate of Bassett (1925) 196 Cal. 576, 238 Pac. 666; Note (1927) 15 CALIF, L. REv. 164. 
I believe that justice would be better served by the repeal of the provision relating to pretermitted heirs living at the date of the will. Furthermore, the effect of such a change in eliminating fraudulent claims to heirship is apparent.

Sec. 162. Legacies other than those to a widow or for maintenance are not deliverable and do not bear interest until one year after the testator's death. In view of the recent shortening of the time for probating an estate ${ }^{20}$ should not the legacies be made payable and bear interestafter six months? If the estate remains in probate after the time to present claims has expired, it is generally for the benefit of the residuary legatees and devisees, and the delay should not be at the expense of the specific legatees.

\section{Succession}

Sec. 226. The English statute of succession was amended a few years ago so as to cut off the right of inheritance by distant relatives. ${ }^{21}$ There is no good reason why cousims, at any rate those beyond the fourth degree of kinship, i.e., first cousins, should have any riglit of inheritance. Such distant relatives have no such contact with the decedent as to make them depedent upon him or to bring them within the circle of his warm affection. Without injuring anyone, the state could as well take all, in heu of merely a portion of the estate, by tax, where there are no relatives closer than descendants of brothers and sisters, and the decendent has not cared to make testamentary provision for lis cousins.

Not only does the state at present make this uncalled for gift to people rather remotely related to the decedent, but the present statute is the cause, every once in a while, of prolonged hitigation to establish relationship. People whom the decedent did not know and who did not know the decedent appear to claim his estate. There have been several long and costly trials in the courts of San Francisco between groups of relatives none of whom claimed to be related more closely than in the fifth degree.

There is, of course, the constant invitation to heir hunting and false testimony, as well as the burden placed upon the courts. This waste of the time of the courts and of the taxpayers' money serves no useful public or private purpose.

Sec. 227. Ordinarily, when a person dies leaving neither spouse nor issue, the estate goes to the parents or to the survivor of thein. But under this section if a child dies without having been married, any property which came to him by succession from a parent goes to the other children

20 The time for presenting claims has heen cut down from ten months to six months, and that within which to contest a will from a year to six months. Cax. ProB. CoDE $\$ \$ 700,380$.

21 Administration of Estates Act (1925) 15 Geo. V, c. 23, §46. 
of that parent. For example, if such a child has inherited property from its father, that property goes, upon the child's death, to his brothers and sisters, instead of to his mother, as would be the case with property acquired in any other manner.

The question arises, is not the relationship of much more cousequence than the origin of the estate? If the mother is ordinarily the heir, is there any good reason for ehminating her and substituting the brothers and sisters, merely because the property came from the father? A certain amount of confusion is bound to arise where the statute contains a general rule and exceptions to satisfy particular cases. As I do not believe the section under discussion accomplishes any needed purpose, I would favor its repeal for the sake of simplicity.

Secs. 228-9. I have already called attention to the fact that these sections now state the law as the former code provision was interpreted in Estate of McArthur, ${ }^{22}$ by eliminating the words "widow or widower." Whether the court riglitly or wrongly interpreted the statute is no longer a matter of concern. The question remains: Is the provision as now worded a just one? Is there any reason why a surviving spouse should be excluded from all inheritance merely because the decedent acquired the property in question from or while living with a previous spouse?

For example: John Brown marries Mary Smith, and through his business activities acquires a fortune of $\$ 100,000$. His wife dies and he marries Susan Black. They have no children, but they have a long and companionable life together. No new community property is acquired, because Brown is able to live on his income. When he dies, what becomes of his property? If he has forgotten to make a will, or if his will can not be discovered, we find not only that one-half of his property will be inherited by the relatives of Mary Smith, perhaps the grandchildren of her brothers and sisters, whom John Brown never knew or heard of, and who probably never knew Joln Brown, but that the other one-half goes to John Brown's relatives, who may be no nearer than nephews or nieces. The poor widow is astonished, to say the least, to find that she doesn't get a cent.

In deference to the memory of Mary, not only do her kindred come in for half of the estate, but for some inscrutable cause the other half, instead of going to or being shared in by the widow, goes to John Brown's kindred. As I have already suggested, the relationship between the decedent and the relatives who survive him should be of more importance in determining succession than the origin of the property which he owns when he dies. Either these sections should apply only where the decedent leaves neither spouse nor issue, or else specific provision should be made for a widow so that she would at least get some share of the estate. 
Sec. 230 was inserted in the draft of the Probate Code before the decision in Estate of MCArthur was published, and when I assumed that "widow or widower", as used in the statute, referred to a person who died without leaving a surviving spouse. Subdivision 8 of section 1386 of the Civil Code, now appearing as sections 228 and 229 of the Probate Code, which I have just been discussing, provided for succession down to the descendents of the brothers and sisters of a predeceased spouse and the descendants of the brothers and sisters of the decedent. If there were no such relatives to take under these sections, would the general rule as to succession by next of kin apply, or would the property for which these special provisions were made, or the one-half of it, escheat to the estate?

To remove any doubt there might have been on this point section 230 was added, reading:

"If there is no one to succeed to any portion of the property in any of the contingencies provided for in the last two sections, according to the provisions of those sections, such portion goes to the next of kin of the decedent in the manner hereinabove provided for succession by next of kin."

It was assumed, when this section was drafted, that there was no surviving husband or wife to be taken into consideration. In the McArthur estate, the court, by a process of reasoning which is open to question, succeeded in giving one-half of the estate to the surviving husband, because there was neither parent nor issue of a parent. But in a case arising after the effective date of the Probate Code, this new section would exclude a surviving spouse, even as to the one-half which the court in the McArthur case said he or she could have where there was neither parent, brother, sister or descendant of brother or sister to claim the property, because the new section declares that the property must go to the "next of kin." In return for the criticism that has been made of the $M C A r t h u r$ decision, the judges who rendered that decision are at liberty to criticise the draftsman of the Probate Code for his oversight in not changing section 230, as well as sections 228 and 229, to conform to the McArthur case.

\section{Administration}

Sec. 327. As this section is the first one relating to the publications that are required during administration, it may be an appropriate place to discuss the value of the various publications. The only notice which of necessity nust be published in every estate is the notice to creditors. The publication of such a notice once a week for four weeks probably serves a useful purpose, and $I$ have heard no criticism of it.

If there is no will, notice of the application of letters is given by posting. If there is a will, the notice must be given by publication. The period 
of publication is not unreasonable, and the cost thereof would seem to be justified by the publicity given to this important step.

The publication of notice of sale of real estate is appropriate as a means of notifying prospective purchasers.

As to publications which are required upon seeking leave to lease or to mortgage, the old order to show cause has been abolished and the period of publication very much shortened. Also, a new section of the code $^{23}$ permits leases from month to month at a rental not to exceed $\$ 100$, without publication or order of court, so some of the objections to the requirement of publication have been removed. The value of these publications, however, may be questioned. Ordinarily the lessee or the lender has been found through private negotiations, and the likelilood of better offers being obtained through means of a publication seems rather remote. The principal function of notice of these applications would seem to be to inform those interested in the estate, so that they may point out the disadvantages or the lack of necessity of the proposed lease or mortgage. A postal card would seem to serve the purpose of such a notice much better than a publication.

Sec. 352. When there is an application to prove a lost or destroyed will, the court is authorized by this section to restrain an executor or administrator previously appointed from any acts or proceedings which would be injurious to those claiming under the lost or destroyed will. Why should not this power be extended to the probate court in the case of an application to prove any will, whether lost, destroyed, or physically extant?

Sec. 371. In the contest of a will a jury trial may be had upon any question "affecting the validity of the will." This does not include the question of identity or legitimacy of a contestant. If a jury trial is permitted at all, why should not the jury pass upon all conflicts in the evidence? Perhaps jury trials should be avoided, and therefore the province of the jury in will contests should not be enlarged. But it would seem to be more logical to do away altogether witl the jury trial in such cases, or else leave all questions of fact to the jury, as in other sorts of actions.

Sec. 385. The substance of the decision in Estate of Moore, ${ }^{24}$ has been incorporated in this new section in this language:

"Failure to contest a will does not preclude the subsequent probate of another will of the decedent."

The section, as a matter of fact, does not go quite the full length of the decision, which is to the effect that whether a will be contested or not, and notwithstanding a judgment against the contestant, the docu-

23 Cat. Prob. Code $\$ 844$.

24 (1919) 180 Cal. 570, 182 Pac. 285. 
ment in question is merely established as a testamentary act, not as the last testament. Justices Angellotti and Lawlor, who dissented, and Justice Olney, who, together with the dissenting judges, voted for a rehearing, ${ }^{25}$ point out the advantages of considering the probate of a will, the time to contest which has elapsed or which has successfully withstood a contest, as a proceeding in rem and a conclusive determination that the document is the last and only will of the decedent.

If it should be deemed advisable to amend the statute to conform to the opinion of these dissenting judges, a somewhat similar question would arise, namely: Should the fact that a person died intestate be conclusively determined by a decree distributing the property under the laws of succession? Under the present procedure there is no question but that the legal title passes by a decree of distribution, but the distributees, either in the case of a will or in the case of intestacy, could be held as trustees of the property in the event of the subsequent probate of a will leaving the property to others.

Undoubtedly there should at least be some statute limiting the time within which a will could be offered for probate after an estate has been distributed. Not even the rights of purchasers or incumbrancers of real property in good faith and for value, derived from a person claiming by succession, are protected until the lapse of four years after the decedent's death and the failure of anyone to record within that time a notice of a claim under a will. ${ }^{26}$

Sec. 422 gives the priorities with respect to persons entitled to letters of administration. The public administrator is given preference over anyone who is not related to the decedent: The same priority obtains ${ }^{27}$ in the appointment of an administrator with the will annexed, in the case of a domestic will, where no executor is appointed by the will or where the one appointed dies or declines to act. But in the case of a foreign will, either the executor "or any person interested in the will" may obtain letters. ${ }^{28}$

That is to say, the assignee of an interest in the estate, although a stranger in blood to the testator, has priority over the public administrator in the case of a foreign will. Why the different rule? Should not any resident of California, who has an interest in the estate, whether directly under the will or by assignnient, have preference over the public administrator?

Possibly a reason for not agitating the question is the likelihood that the public administrators would seek to straighten out the inconsistency

25 Which was denied. (1919) $180 \mathrm{Cal} .570$ at p. 588, 182 Pac. 285.

26 Cat. Prob. Code $\$ 322$.

27 Ibid. $\$ 409$.

28 Ibid. $\S \S 361,409$; Estate of Rankin (1912) 164 Cal. 138, 127 Pac. 1034. 
by having given to them the priority now given to the "person interested" in a foreign will.

Sec. 441. Since the amendment adopted in $1927,{ }^{29}$ the only notice required upon an application for letters of administration is the posting of a single notice at the court house. I have not had time to give this question any study, but a doubt at once arises in my mind as to whether such a notice constitutes due process of law so as to bind parties upon the principle of constructive notice.

Due process implies that a person is entitled to his day in court after receiving notice of the proceeding against him, either personally or, where such service cannot be had, by some widespread public notice such as publications or postings. A single notice posted at the court house is no more general nor public than the entry in the county clerk's register of the commencement of a new proceeding. In fact, the index to the register would be even more reliable than the unindexed notice at the court house steps. I think this question is worthy of investigation by someone who has the time and inclination. It is a very practical question.

Sec. 461 . For the past ten years the appointment of a special administrator could be made only "upon such notice to such of the persons interested in the estate as the court may deem reasonable." The purpose of the notice was to safeguard against an inconsiderate ex parte appointment. The desire for haste, however, has led to appointments being made without notice, the court declaring that it deemed "no notice" to be reasonable. Recently the supreme court held that all appointments where no notice whatever was given were void..$^{30}$ The last legislature, in addition to passing an act validating all appointments of special administrators which had been made without notice, also amended the Probate Code to provide that the appointment may be made "without notice," or upon such notice as is deemed reasonable.

Perhaps the history of this section proves the futility of requiring a notice. The cautious judge would require that the principal heirs, if within reach, be notified of the petition, at least by letter or telephone, but where the judge treats the petition as a mere matter of routine, he would probably accept the petitioner's proposed form of order, requiring merely the posting of notice for one day, which, in most cases, would be as good as no notice. The need for quick action makes it inadvisable to provide for any extended notice, so that the matter really has to be left to the care and discretion of the judge.

Sec. 584. Personal representatives may invest the money of decedents in securities of the United States or of this state. By Chapter 133 of the

29 Cal. Stat. 1927, c. 272.

30 Olcese v. Superior Court (1930) 210 Cal. 566, 292 Pac. 964. 
laws of 1927 , the legislature attempted to authorize the investment of funds of decedents in "investment certificates" of building and loan associations. It seemed to the code commissioners that this act, which purported to authorize the investment of estate funds in one particular kind of private security, was unconstitutional as being in controvention of section 25 of article IV of the constitution. For that reason section 584 of the Probate Code contains no mention of the authority supposed to be conferred by the 1927 act.

There does not seem to be any good reason for permitting estate funds to be invested in unsecured "investment certificates" and not in bonds of the City and County of San Francisco, bank stocks, public utility and other seasoned securities. Whether the field of authorized investments should be extended is questionable. Since the personal representative holds the funds only temporarily, the existing provision would seem to suffice.

Secs. 600-5. For some time past the bar has considered the appointment of three appraisers a useless expense, oftentimes amounting to a scandal, because of the petty graft involved. The inheritance tax appraiser, or his clerk, ordinarily does whatever work is required, the other appraisers merely signing their names and presenting bills sometimes amounting to $\$ 100$ apiece or more. The State Bar recommended to the last legislature an amendment to the law which would do away with this judicial patronage, now made use of by only two or three judges in the state, by permitting the appointment of three appraisers only when requested by the personal representative or someone interested in the estate. This bill ${ }^{31}$ passed the Senate but was defeated in the Assembly on the last day of the session by a vote of 17 ayes and 49 noes. $^{32}$

So far as I have been able to ascertain no one in or out of the legislature suggested any reason why this bill should be defeated, except that it would take away a piece of patronage from a few judges, and result in a financial loss to certain persons accustomed to receive appointment as appraisers, including one or more members of the legislature. The inheritance tax appraiser performs every service that is necessary in appraising the estate. Where the estate is large and consists of various classes of property, the inheritance tax appraiser has experts whom he may call in to fix the values of works of art, jewelry, stocks of goods, real estate or what-not, and who can perform the services much more satisfactorily than the poltical appointees of the court.

Sec. 630. This section evinces a desire to place the property of decedents in the hands of the persons entitled to it, without the formality of administration. Money in bank, property in safe deposit boxes, shares

31 Senate Bill 214.

32 Assembly Daily Journal (May 15, 1931) 90. 
of stock, etc., including, by amendment at the last session, money due a decedent as wages, may be paid out or transferred to anyone making an affidavit showing that he is entitled thereto as the successor of the decedent. No bond is required of the affiant. Perhaps this procedure could be extended to more considerable estates, with a provision for the delivery or filing of a bond to secure creditors or other persons who may establish an interest in the property in the event of proceedings for administration. This would enable heirs to receive their property without the cost and bother of administration. I do not anticipate that the bar will take the lead in the advocacy of such a step.

Sec. 645. By this section the widow or minor children are entitled to receive the property of a decedent if its value does not exceed $\$ 2500$, without subjecting the property to the payment of the claims of the decedent's creditors. While a desire to be generous with the widow and minor children may be laudable, I have never been able to see why they should be taken care of by depriving the creditors of what in common justice is really their property. The state performs a charitable act, but gets its ammunition by confiscating the property of the creditors.

Prior to the amendment which took effect in 1929, the widow or minor child could insist upon receiving the decedent's property, to the exclusion of the creditors, even though they themselves were already well to do. By the 1929 amendment the section is inoperative as to a widow or minor child who has other estate over $\$ 5,000$ in value. I still do not see why the groceryman or butcher or the hired man or a carpenter or painter who had been employed by the decedent should be compelled to sacrifice his claim for services or materials to enable the widow or child to build up an estate of the value of $\$ 7,500$. It seems to me that the provision of a family allowance to meet the emergency caused by the death of the provider is all that the family should reasonably expect.

Sec. 660. As amended during passage through the assembly, the law now provides that the court "in its discretion" may set apart to the surviving spouse or to the minor children the property of the decedent which is exempt from execution. Formerly the spouse or minor children had an absolute right to receive this property. If they have no such absolute right, by what rule is the court to be guided in exercising its discretion to set the property aside? Will an order be erroneous if it sets apart property to persons who already have a considerable amount of property and who are not in necessitous circumstances? I believe the statute should be made more definite.

Secs. 754, 785. Prior to the year 1919, an administrator desiring to sell property had to obtain an order adjudging that the sale was necessary or beneficial. After the sale was made, it had to be confirmed by another order. This procedure seemed cumbersome, and the legislature simplified 
the proceeding by doing away with the order of sale. The result is somewhat curious. The administrator makes a sale and then the matter is brought before the court to determine, not only that the sale was properly made and that an adequate price has been received, but that the sale was necessary or beneficial to the estate. (A matter in which the purchaser has no concern.) The cart is put before the horse.

It would seem, on principle, that a better price for the property would be received if the purchaser was assured that the matter of the propriety of the sale had previously been determined. However, since the purchaser must in any event face the possibility of an increased bid upon the return of sale, he knows that his purchase is merely tentative, and in practice the theoretical objection which I have raised may not be of much importance. Nevertheless it seems wrong that the purchaser should be confronted with the necessity of proving the propriety of the sale.

Sec. 844. This new section permits leases to be made without an order of court and the incidental expense and delay of publication ordinarily required, where the tenancy is from month to month or for a term not extending beyond the time for presenting claims, and the rental does not exceed $\$ 100$ a month. Perhaps it would have been better to have extended this provision to leases not exceeding a term of one year. Since the term of leases is seldom less than one year, such a provision would simplify the leasing of stores and offices. Such leases would ordinarily be a benefit rather than a detriment to the distributees of the estate.

Sec. 860, authorizing an administrator to exchange property of the decedent for other property ${ }^{33}$ was the outcome of a suggestion made by an attorney to a section of the State Bar, because of a particular case, that some provision should be made whereby boundary lines of real property could be straightened out prior to distribution. But the broad language of the section adopted has led, I am informed, to a considerable activity, in Los Angeles county as least, in bartering the assets of estates. The wisdom of this practice may readily be doubted.

Sec. 1000. A partial distribution may not be obtained until after the lapse of four months from the issuance of letters. This may not have been an undue delay when communication was less rapid, when creditors had ten months within which to present claims, and when one year was given in which to contest a will. Under present conditions there is no justification for such a long delay. After the lapse of sixty days, perhaps even of thirty days, the court should be able to make a fair estimate of the claims that are likely to be presented, so as to determine the amount of the bond that is demanded. I suggest that partial distribution should be authorized at an earher date.

33 Based upon CaI. Code Crv. Proc. \$1576a, adopted in 1929. 
Sec. 1023. When an heir, devisee or legatee dies before distribution, his share of the estate may be distributed "to the representative of his estate." A very technical clain may be nuade that the title to the property vests in the representative as a trustee, rather than in the unknown persons entitled to the second decedent's estate, subject to administration; a result which would necessitate the execution of deeds by the representative to the distributees of the second estate. I should think the title companies would desire to have this uncertainty removed.

Secs. 1080-2. I have already pointed out that these sections take the place of section 1664 of the Code of Civil Procedure, and furnish a simple procedure for determining heirship. It may be claimed that the substituted procedure is too sketchy. The hearing is brought about by the filing of a petition and giving notice of the hearing by the usual posting, with special notice to those who have filed requests for the same.

Perhaps it would be wise to require the petitioner to mail notice of the petition to any persons whon the record discloses as having an interest in the estate which might be affected by the proposed decree. If such a notice is advisable, it of course should likewise be required in the case of a petition for distribution. Personally, I favor a provision by which anyone known to have an interest in the estate would receive at least a postal card informing him of these most important steps in the administration of the estate; but the majority of the profession may be opposed to the imposition of additional requirements.

So far as pleadings are concerned, I believe the proposed procedure to be both simple and sufficient:

"Any person may appear and file a written statement setting forth his interest in the estate. No other pleadings are necessary and the allegations of each claimant shall be deemed to be denied by each of the other claimants to the extent that they conflict with any claim of the latter."

The court should be able to understand what the issues are from these statements, just as well as it could fronı cross-complaints, answers to cross-complaints, etc.

Secs. 1100-6 provide a proceeding for partition or allotment before distribution, the order to be controlling upon proceedings for distribution unless nodified for good cause. I look forward with considerable interest and some trepidation to see how this procedure will work out. I drafted a suggested procedure and submitted it not only to the other members of the commission, but to a number of other lawyers. No improvement upon the draft having been suggested, it was inserted in the code and is now the law.

Without doubt, experience under the new procedure will indicate improvements that may be nuade. The commission debated the question whether or not the allotment should be subject to modification "for good 
cause" upon proceedings for distribution. It is uncertain what the courts will deem "good cause"; and of course, with this provision in the law, the decree of allotment will be merely tentative until the decree of distribution is made. However, the majority of the commission thought that it was better to leave the decree open for modification to meet such a case as a great change in the market value of securities, inasmuch as the person to whom a share is alloted cannot make much use of it until it is distributed to him.

Sec. 1411, which purports to prohibit the appointment of any person ineligible to citizenship as the guardian of any estate which includes real property, would seem to be unconstitutional under the holding in Estate of Yano. ${ }^{34}$ This decision was rendered in May, 1922. The code section in question, although substantially the same as the act held unconstitutional, was not adopted until 1923, and the authors of the 1923 act believed that they drafted the new section of the code so as to escape the application of the decision in the Yano case. For this reason, the commission did not feel justified in dropping the section out of the new Probate Code, believing that the matter of its constitutionality should be passed upon by the courts.

Sec. 1471. It is rather curious that the court sits without a jury in passing upon a petititon for the appointment of a guardian of an alleged insane or incompetent person, but that after such a guardian has been appointed the person who has been declared insane or incompetent may have the question of his restoration to capacity tried by a jury. It is hard to figure out why, if a person should be granted a trial by jury on the question of restoration, he should not be entitled to a jury upon the original application for the appointment of a guardian. Rather than suggest such an extension of the jury trial, however, I would suggest that the question of restoration be left to the judge rather than to a jury. The jury is a poor medium for determining sanity and mental capacity.

Sec. 1485. "A testamentary guardian need not give bond unless required by the court from which the letters issue." Is this a sufficient protection for the ward? Would it be better to provide that the guardian need not give bond "when the will provides that no bond need be given," unless required by the court? One objection to a change in the law is that wills have already been drawn appointing guardians, with the presumed knowledge that under the present law a bond will not be required. As against this argument, it is doubtful whether the average testator who has nominated a guardian for a beneficiary under his will understands that such nomination avoids the necessity of the guardian being put under bond. If a testator desires an executor to serve without bonds, he

34 (1922) 188 Cal. 645, 206 Pac. 995. 
is required so to state. It would seem reasonable to make the same provision with regard to the nomination of a guardian. The code commissioners were divided upon this subject, the majority favoring the existing law.

Sec. 1550. What need is there for appraising the property of every ward? Would it not be sufficient to require the filing and recording of an inventory and provide for an appraisement only upon motion, and the proof of some sufficient reason therefor?

Perry Evans.

SAN Francisco, CaIIforNia. 